\title{
Analysis of the causes and effects of landslides in the Carpathian flysch in the area of Milówka and evaluation of their prevention methods
}

\author{
MAŁGORZATA JASTRZĘBSKA, MARIAN ŁUPIEŻOWIEC \\ Faculty of Civil Engineering, Silesian University of Technology, Gliwice, Poland
}

\begin{abstract}
Analysis of the causes and effects of landslides in the Carpathian flysch in the area of Milówka and evaluation of their prevention methods. The paper presents a comprehensive study on the causes and effects of landslides occurring in the gmina Milówka (gmina is the administrative district in Poland, similar to a commune or municipality) from 1947 until today. The analysis includes the identification of probable causes of landslides and a discussion of possible remedial methods, including preventive ones. The following were considered: results of laboratory, geophysical and seismic tests; meteorological data; vegetative and transpirational properties of plants and agricultural crops; intensity of farming; forest clearance. Attention was also paid to the tree-ring eccentricity among spruces. Additionally, a numerical analysis of the current landslide stability was carried out in the Z_Soil program. Finally, it was found that determining the exact value of the stability coefficient is not possible due to the numerous assumptions necessary for the numerical analysis. However, it is possible to predict with high probability which of the slopes are threatened with landslides.
\end{abstract}

Key words: landslides, stability analysis of the slopes and escarpments, gmina Milówka

\section{INTRODUCTION}

The landslide problem concerns mountainous areas (but not only) around the world. Data collected by the Polish
Geological Institute shows that 95\% of the landslides in Poland occur in the Carpathian area, some occupy from 30 to $40 \%$ of the gmina's area. The first attempt to list the landslides in Poland was undertaken in the years 1968-1970.

At that time, they were estimated at 8,500 , and 2,970 of which posed a threat to residential buildings. Since then, landslide phenomena have intensified to the alarming level (www.pgi.gov.pl). In 2010 a special landslides counteracting program was introduced called system ostony przeciwosuwiskowej (abbreviation SOPO). The primary objective of SOPO is an ongoing monitoring of threatened areas (Fig. 1). The basis of activities is an underground observation (piezometers, inclinometers) and overground (GNSS satellite scan, laser scanning, interferometric synthetic aperture radar - InSAR, rain gauges).

The authors seek to determine the correlation between this phenomenon and atmospheric precipitation and anthropogenic factors, such as the forest clearance or shrinkage of agricultural fields on the slopes.

Transpiration properties of plants play a significant part in maintaining water 


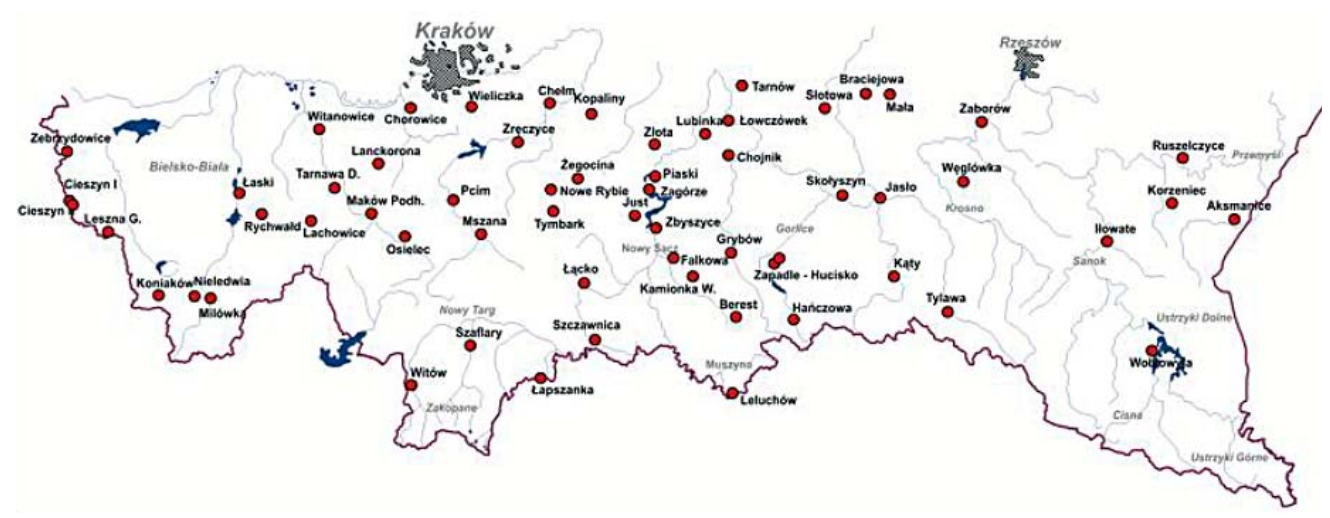

FIGURE 1. A map of landslides with SOPO monitoring (www.pgi.gov.pl)

balance in the substrate. For example, the alfalfa needs 8591 and a larch needs 1,1651 of water in order to produce $1 \mathrm{~kg}$ of dry mass. This is the reason why in the case of large areas threatened by landslides, solutions developed by biotechnical engineering (including the construction of terraces, regulation of soil-water relations, afforestation, etc.) are introduced (Begemann and Schiechtl 1999).

Each proposed solution (engineering or biotechnical) is preceded by a thorough analysis of a specific case, which is extremely complex in relation to the Carpathian flysch.

Flysch is a heterogeneous, discontinuous and anisotropic medium. The landslide phenomena occurring in it most often arise as a result of shifting of weak weathered top layer following the underlying strong layer (usually rock), caused by a change in water relations and a decrease in the strength parameters of the weak layer (Instruction 2009). For this reason, each analysis concerns many threads and contains elements such as: reconstruction of the adverse phenomena history in a given area, creation of computational model, assessment of the accuracy of geological and geotechnical research on rock mass and appropriate interpretation of the obtained parameters, determination of the impact of vegetation on soil and water conditions, determination of filtration coefficients, and analysis of possible solutions, e.g. by draining water out of the colluvium of landslide.

In the 1980s a new direction in determining the landslide phenomena called dendrogeomorphology appeared (Shroder 1980, Butler 1987). It is based on the conviction that the external disturbances correspond to changes in the anatomy of wood e.g. the deconcentricity of the tree-growth radial. This idea was developed by, among others, Wistuba and Malik (2011), followed by Wistuba et al. (2012, 2013, 2014) by introducing the substrate sliding activity index (deconcentricity index method). When comparing deconcentricity of the tree-growth data with rainfall data, it is possible to reconstruct previous mass movements of the ground and determine the threshold conditions triggering such phenomena (dendrochronology). The effectiveness of the 
method was confirmed in the studies conducted on the Keprnícký landslide (Hrubý Jeseník, Eastern Sudetes, the Czech Republic; Wistuba et al. 2012) and on the Milówka landslide (foots of Prusów Mt 1,020 m a.s.l., southern Poland, flysch Western Carpathians; Wistuba et al. 2013, 2014). The above mentioned studies have shown that dendrochronological analysis of growth disturbances in trees is a promising approach to determine landslide hazards in the extensive mountain ranges. It can serve in early warning of the risk related to catastrophic landsliding.

In the context of the presented information, a comprehensive analysis of the causes and effects of landslides occurring in the gmina Milówka from 1947 until today has been conducted.

\section{MATERIAL AND METHODS}

\section{Inventory of landslides and substrate exploratory study}

Inventory of the existing state was conducted on the basis of the site inspection of landslide in Nieledwia, in Siedloki and on Prusów mountain and on the basis of materials received from the Polish Geological Institute (PIG) and from the

\section{a}

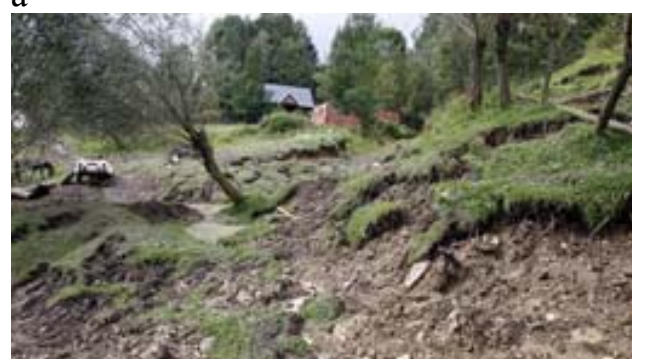

Municipal Office of Milówka (Cempura et al. 2009, Documentation 2010a, b, 2011a, b, 2016).

A described landslide is located in Milówka in the lower and middle part of the southern slope of the Prusów Mountain. At the foot of the slope is located the stream called Salomonka flows. The area of landslides was mostly dominated by meadows with single trees, orchards, arable lands, and only the lower part of the slope was covered by mixed forest. The access road to the hamlets above the stream Salomonka was located on the side of the stream where the landslide forehead is now situated. The landslide is an old landslide, and although it was considered to be inactive. Studies of deconcentricity of tree-rings conducted by the team of Wistuba et al. (2014) in fact showed its alternating activity in 1947, 1950, 1962, 1968, 1977, 1993, 1997, 2004, 2007 and 2008. On 3 September 2010 there was another full activation, which resulted in catastrophic consequences (Fig. 2). The cause of the landslide was the infiltration of rainwater into the soil mass. The landslide covered the area of almost 12 ha, and the average ground movement speed was $2 \mathrm{~cm} / \mathrm{h}$. It is worth noting that on 5 September 2015, the whole landslide area was

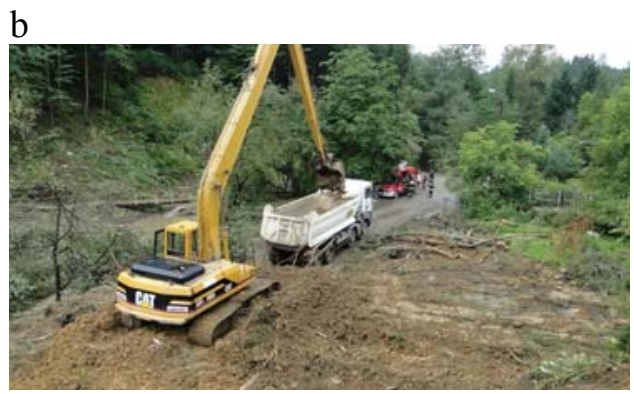

FIGURE 2. General view of the damage on the Milówka Siedloki landslide in September 2010 (www. onet.pl): $\mathrm{a}$ - a part of a landslide; $\mathrm{b}$ - destroyed regional road 
still subject to massive movements on its entire surface, resulting in the destruction of the county road and tightening the Salomonka riverbed (Fig. 2). In the upper part of the landslide, surface displacements amounted to over $6 \mathrm{~m}$ (Fig. 3). Within the colluvium of the landslide there were numerous secondary niches, crevices and cracks (Fig. 4) filled with water during rainy periods. The strong hydration of the

a

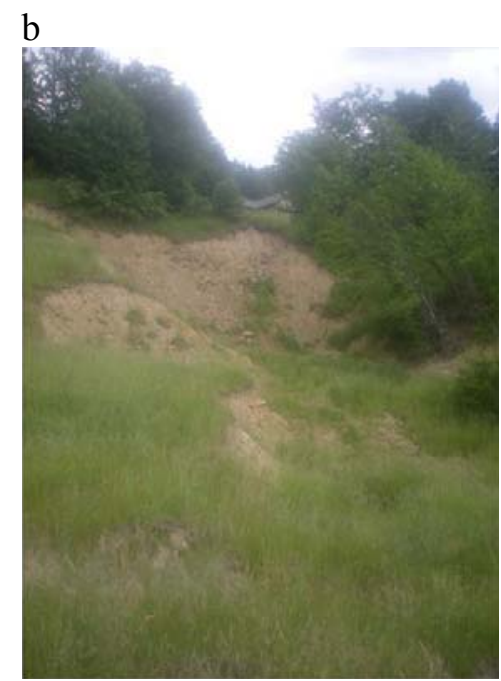

FIGURE 3. General view of horizontal displacements on the Milówka Siedloki landslide in June 2015 (Dziedzic and Golan 2016): $\mathrm{a}$ - upper edge of a landslide; $\mathrm{b}$ - main landslide threshold

$\mathrm{a}$

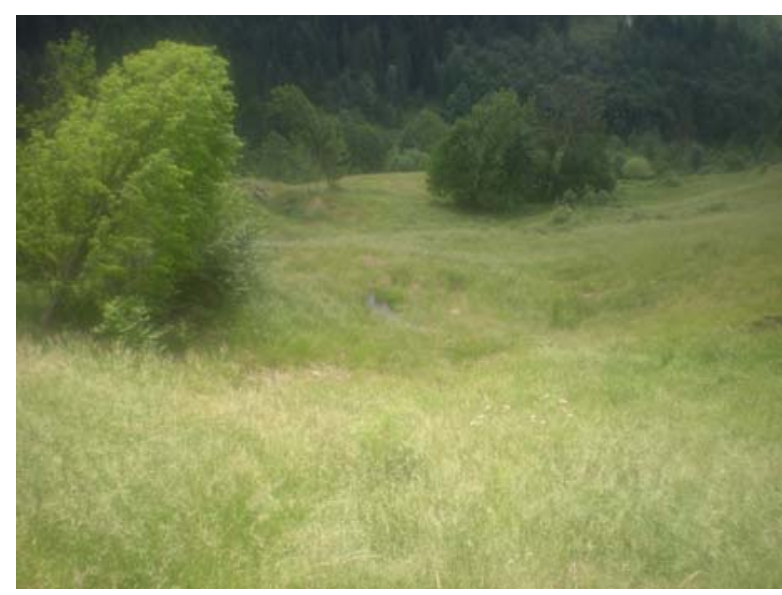

$\mathrm{b}$

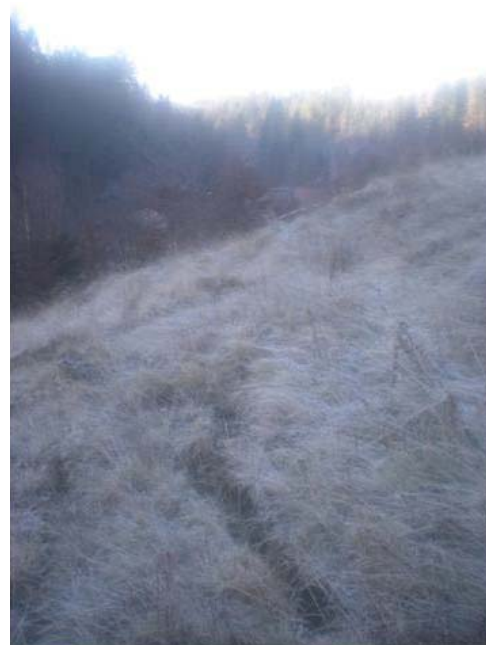

FIGURE 4. General view of the colluvium of the landslide in Milówka Siedloki (Dziedzic and Golan 2016): a - "a drunk forest", niche filled with water; b - visible cracks - winter 2014/2015 
colluvium is also confirmed by presence of the typical plants for wetlands. Finally, the following were destroyed: four residential buildings, four outbuildings, one summer house, one building under construction, low and medium voltage line, telephone line, access roads and regional road (including 2 bridges). Area protection - related works after the disaster cost PLN 3.2 mln (Gardas 2011).

At the same time, a research program was initiated. A set of geotechnical tests was carried out at the request of the PIG at the Institute of Geotechnics of the Cracow University of Technology (Documentation 2011b). The tests included the basic recognition of the physical characteristics of six samples with an intact structure (natural water content $w=14.42-36.32 \% ; \mathrm{CaCO}_{3}$ content: $1 \%$ and $1-3 \%$; bulk density $\gamma=19.6$ $-23.3 \mathrm{kN} / \mathrm{m}^{3}$; grain size distribution) and strength characteristic based on $\mathrm{CD}+\mathrm{u}$ tests $\left(\varphi^{\prime}=27.8^{\circ} ; c^{\prime}=5.3 \mathrm{kPa} ; \varphi^{\prime}=25.6^{\circ}\right.$, $\left.c^{\prime}=7.9 \mathrm{kPa}\right)$. Samples for testing were taken from six different depth levels up to $9.0 \mathrm{~m}$, on which the movement of soil masses was observed. The ground water was drilled at a depth of $2.75 \mathrm{~m}$. The borehole was deepened to $30 \mathrm{~m}$ and used for inclinometer observations. During the observations three potential slip surfaces were found, respectively at the depths of: $12.9,20.9$ and $21.8 \mathrm{~m}$.

Laboratory tests were supplemented with geophysical tests carried out by Przedsiębiorstwo Badań Geoficznych Sp. z o.o from Warsaw (Documentation 2011a). The location of the profiles is shown on the map (Fig. 5). The seismic profile is marked with a blue colour, and the geoelectric profile is marked with an orange colour (the ERT, electro-resistance method).

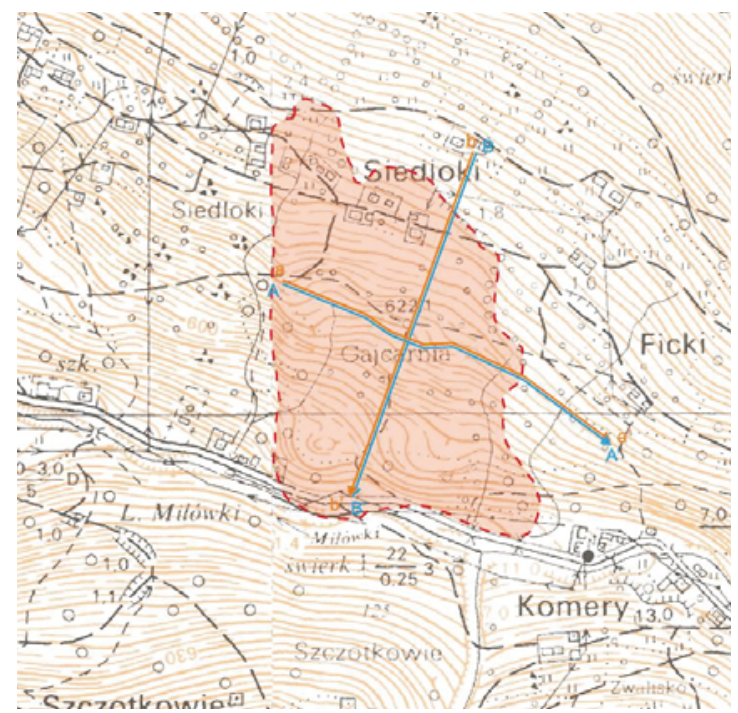

red line - landslide border; orange line - geoelectric profile; blue line - seismic profile

FIGURE 5. Map of the geophysical works on the landslide in Milówka Siedloki (Documentation 2011a) 


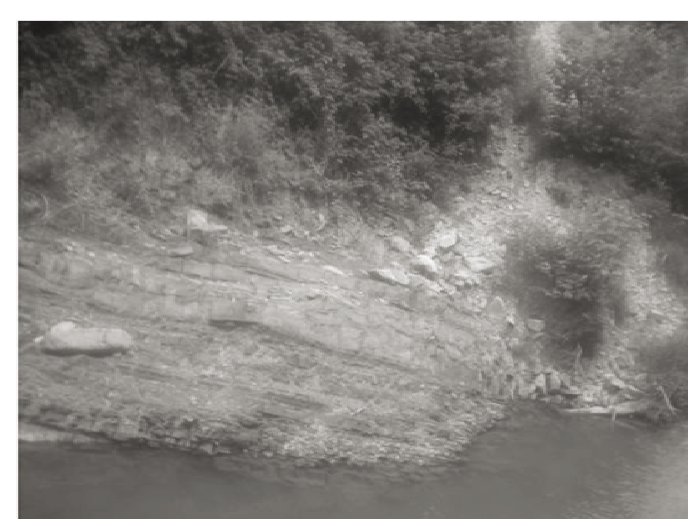

FIGURE 6. The argillaceous schist outcrop in the bottom of the stream (Dziedzic and Golan 2016)

On the basis of seismic profiling along the slope (Documentation 2011a), three layers with different parameters were separated. The highest layer with the smallest thickness has been classified as clay and debris with a maximum thickness of about $5 \mathrm{~m}$. The middle layer was classified as a strongly cracked and damaged rock mass, with a thickness ranging from $8 \mathrm{~m}$ to about $30 \mathrm{~m}$. The depth of this layer represents the potential slip surface. The third, lowest and intact layer is a solid rock substrate made of sandstone interlaced with argillaceous schist, which is very well visible in the stream bed, as shown in Figure 6.

All slip surfaces are located in layers of black marly shales that are interlaced with cracked sandstone. It is a very unfavorable arrangement due to the accelerated infiltration of water into the shales (towards the surface of the slip), which significantly reduces their strength.

\section{Landslide prevention methods}

Prevention methods used for building slopes are extremely expensive due to very large soil masses, which must be well secured. Therefore, they are used very rarely. The most common method is the drainage of the terrain as a way to protect the land against the formation of landslide or its activation. Correct water drainage is very important for ensuring stability, because the immediate cause of most landslides are heavy rains. Therefore, maintenance of existing running waters should be carried out so that rainwater from the upper parts of the slope can be effectively drained. In addition, cultivation of appropriate plant species is also important. It is not surprising that landslide activation is often associated with negligence in this area.

Limitations concerning the use of the slope, which mainly consist in the reduction of sliding loads are preventive methods as well. It is not surprising that in areas threatened by landslides, spatial development plans definitely limit development of constructions and in the case of such planning permission, it is necessary to carry out a series of additional analyses. Obviously this way safety margin increases, however, it does not constitute an additional reinforcement for the soil or rock substrates or a support for the ground masses. Retaining structures, that 
can be considered supporting methods, are made in places particularly exposed to the risk of large material losses, such as roads or buildings. Retaining structures are solid concrete or stone retaining walls (investments made in the past), as well as cantilever retaining walls, counterfort retaining walls or anchored retaining walls. However, it should be noted that this type of support is made only on very short fragments and does not constitute a protection for the entire slope. They are implemented in places particularly exposed to the occurrence of ground mass movements or where the consequences of landslides are particularly severe. This applies to mainly roads or existing buildings, especially those inhabited. Finally, the last of the discussed methods of securing the slopes is soil nailing. This method consists in introducing ground nails of specified length into the subsoil (it depends on the location of the hypothetical slip surface), which sometimes reaches even 20-30 m. This solution is very expensive and is only used in areas requiring special protection. What is more, nails are not usually used to protect the entire slopes that cover extensive areas.

The safety of slopes is enhanced by monitoring, which may be perfectly described as the observational method of geotechnical design, which is provided by the EN-1997-1:2004 standard. It is necessary to provide displacement control at specially installed measuring points. Inclinometer observations are crucial because they enable very fast detection of an activated landslide and the location of slip surfaces. Proper monitoring allows to take the immediate security measures in a situation when the measurement results may indicate the risk of landslides activation.

\section{Methods of slope stability analysis}

The escarpment and slope stability analysis is carried out to assess the safety margin with regard to the risk of landslides, sluffs and other similar destructive effects on the slope surface. As was previously mentioned, these phenomena may be a threat to life or health of people staying nearby, as well as serious material losses. Stability analysis methods can be divided into three groups. The first method focuses on finding a shape of a slope that is located near the limit state. This condition is most often described as the Coulomb-Mohr model, and the parameters determining the stability are cohesion and angle of internal friction. The most popular method is the Sokołowski's method. In order to use it in practice, various types of nomograms have been created (Wiłun 2013). An important drawback of this group of methods is the lack of possibility to include soil stratification (using the weighted mean of parameters value does not solve the problem) and the influence of water flow pressure. Therefore, nowadays this method is very rarely used and its only application is the preliminary assessment of slope stability. The second group of methods that are nowadays quite often used are strip (block) methods. These types of methods are based on the analysis of the equilibrium of thought-separated blocks of soil along the slip surface defined by the user (Madej 1981). Depending on the assumptions regarding cooperation between blocks, the following methods can be distinguished: Fellenius, Bishop, Janbu, Morgernstern-Price and many 
others. The stability factor $(F)$ is defined as the ratio of generalized forces maintaining the system $\left(M_{u l t}\right)$, usually moments relative to a specific point, to the interactions causing the sluff of the soil $\left(M_{\text {all }}\right)$, which can be presented by the formula:

$$
F=\frac{M_{\text {ult }}}{M_{\text {all }}}
$$

The main causes of landslides are: unit weight of solid, water flow pressure and additional loads resulting from, for example, exploitation, while retention forces result from the shear strength of the soil along the slip surface. The strength is usually described by Coulomb's dependence, and the parameters are $c$ and $\varphi$. These methods are very often used for practical issues. Their weakness is the necessity of providing the surface with the initial slip, which should rather be the result of calculations. This type of methods allows to inlcude the inhomogeneity of the ground and the influence of water, which is not possible in the case of methods based on the analysis of the state of stress. Block methods usually do not apply to analyses of three-dimensional issues, although the latter are extremely rare.

A concept that is free from the above drawbacks is the use of the finite element method in estimating the stability coefficient value. After the stress state has been generated in the ground mass of the slope, the procedure of $c-\varphi$ strength reduction is used. The procedure consists in gradual lowering of the values of strength parameters (cohesion and tangent of the internal friction angle), which results in the formation of plasticity zones in the elements where the plasticity surface has been reached. Further reduction of the parameter values requires redistribution of stresses, which is carried out during the iterative procedure. The procedure is carried out until the lack of convergence of iterations is reached, which leads to the mechanism of destruction. The corresponding stability coefficient value is calculated from the formula:

$$
F=\frac{c_{0}}{c_{f}}=\frac{\operatorname{tg} \varphi_{0}}{\operatorname{tg} \varphi_{f}}
$$

where:

$c_{0}, \varphi_{0}$ - values of strength parameters - a perfectly plastic Coulomb-Mohr model of soils accumulated in the slope substrate, estimated on the basis of geotechnical diagnosis;

$c_{f}, \varphi_{f}$ - parameter values at the point of destruction mechanism of the slope.

The value of the factor $F$ greater than 1.00 indicates that the slope is stable, although the safety margin is not always sufficient. A value of exactly 1.00 means that the slope is in the limit state. Values lower than 1.00 cannot be obtained by the above calculation, as it is not possible to generate a state of stress in the substrate at the slope instability. The reduction procedure of $c-\varphi$ can be used if the Coulomb-Mohr or Drucker-Prager model were used for the analysis, parameters are the above mentioned cohesion and angle of internal friction. In the case of other elastic-plastic models, the stability estimation procedure can be adjusted gradually by reducing the values of the parameters determining the location of 
the plastic surface at a given point (stress level method). An undoubted advantage of the presented method is the fact that the surface of the slip is the result of analysis, and it is not preassumed by an user. In addition, it is possible to include many factors in FEM, which are not included in other methods of analysis. These include the layering of the soil substrate, the effect of the groundwater flow pressure, the various types of reinforcements, any slope loading (also dynamic) and many others. The disadvantage of the described method is that the result depends on the effectiveness of the iterative algorithm used during redistribution of stresses. However, differences in this regard are on the safe side.

At this point, it is worth analysing the requirements for the stability factor, which guarantee the safety margin. Of course, the margin will depend on the type of construction (permanent or temporary) and the consequences of stability loss. In the case of small level differences between the subgrade and the base of the slope or escarpment and temporary structures, a sufficient value of the stability factor is 1.10 . The value required for the analysed slope is 1.30 , which means that there is a low probability of a landslide and it guarantees the required safety margin (Kłosiński and Leśniowski 2009). In the case of infrastructure investments, even more stringent requirements are applied. A value of 1.50 is demanded in the case of excavation slopes and motorway embankments and modernization of railway lines, and even 2.0 for new railway investments (Instruction Id-3). It is not difficult to notice that such requirements are not imposed due to safety reasons and further that significant financial efforts are required to strengthen the slopes.

\section{RESULTS AND DISCUSSION}

\section{Analysis of landslides in Milówka}

The area affected by the landslide in Milówka consists of three significant areas: Milówka Nieledwia (on the left side of the Sola River, Nieledwia) and adjacent Milówka Prusów and Milówka Siedloki (on the right side of the Sola river, the mountain called Prusów and the hamlet called Siedloki at its foot).

Landslide in the village of Nieledwia was activated in 2009. It posed a threat on several sections of the S 1437 Milówka-Nieledwia regional road which began to slide down towards the stream called Nieledwianka. After that situation, the slope was stabilized and the road was renovated. Some of the works were carried out in 2009, and they were completed in autumn 2010. Another landslide activated in the hamlet of Siedloki and on the mountain Prusów in September 2010, during the work on the landslide in Nieledwia. It was a result of heavy and prolonged rainfall. Despite the fact that it covered a small area of that was $480 \mathrm{~m}$ long and $300 \mathrm{~m}$ wide, its effects were disastrous (see chapter "Materials and methods"). As a result, it was necessary to: rebuild the road section of $0.5 \mathrm{~km}$ and electric and telephone networks, clear the stream of Salomonka and secure the mountain slope of Prusów.

\section{Landslide of Milówka Nieledwia}

The design office "Zamek" from Kraków designed three retaining walls in the lower, middle and upper part of the village in order to stabilize the regional 
road $\mathrm{S} 1437$. These were retaining ribbed walls with different heights and lengths of dilated segments. The main wall and ribs were $0.3 \mathrm{~m}$ thick. The Gonar rod system with metal heads concreted into a bench of retaining wall and a drainage system for areas located above the road was suggested as an additional security. In the constructed reinforced concrete box, it was possible to re-grow vegetation due to filling it with native soil (the item was included in the analysis of the stability of the system). Therefore, it was a combination of an engineering and biotechnical solutions that blended in with the surroundings very well (Fig. 7). Linear drainage was done behind the central retaining wall on the road side parallel to the axis of the wall, i.e. parallel to the upper edge of the formed landslide, and the rainwater was drained to the absorption wells (Fig. 7b).

Observations from July 2015 confirmed the effectiveness of the applied solutions, especially in the case of the central retaining wall, in which the minimum dilatation and displacement of the dilatation appeared, contrary to the other walls with significant displacements. In addition, no longitudinal cracks in the asphalt were observed, which indicates the stabilization of the displacement and the inhibition of the landslide.

\section{The landslides in Milówka Prusów and Milówka Siedloki}

The risk of mass movements is still real on this location, which is confirmed by the numerical stability analyses. Securing the landslide against further escalation in a large area is practically impossible due to the potential costs. After the analysis of the causes, it was found that future stabilization works should maximally drain this area and reduce the amount of water infiltrating the colluvium. Finally, the surrounding drainage was suggested fo the landslide crown (about 1,500 m), which cuts off the inflow of water from the top of the slope to the colluvium and discharges the rainwater to the nearby Salomonka stream (Fig. 8). Additionally, it was recommended that the colluvium areas should be filled with plants that a

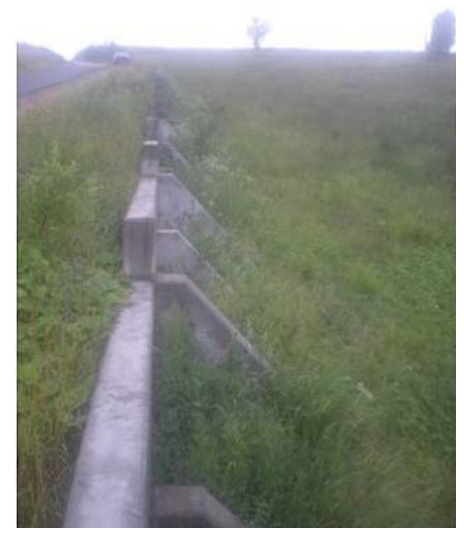

b

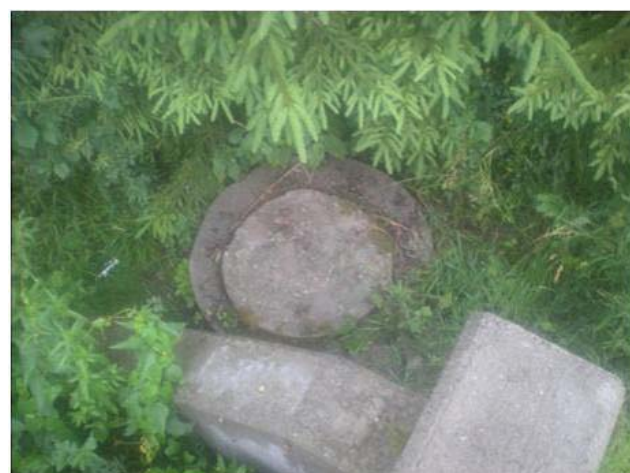

FIGURE 7. Retaining wall on the landslide Milówka Nieledwia (Dziedzic and Golan 2016): a - upper retaining wall; $\mathrm{b}$ - middle retaining wall with an absorption well 


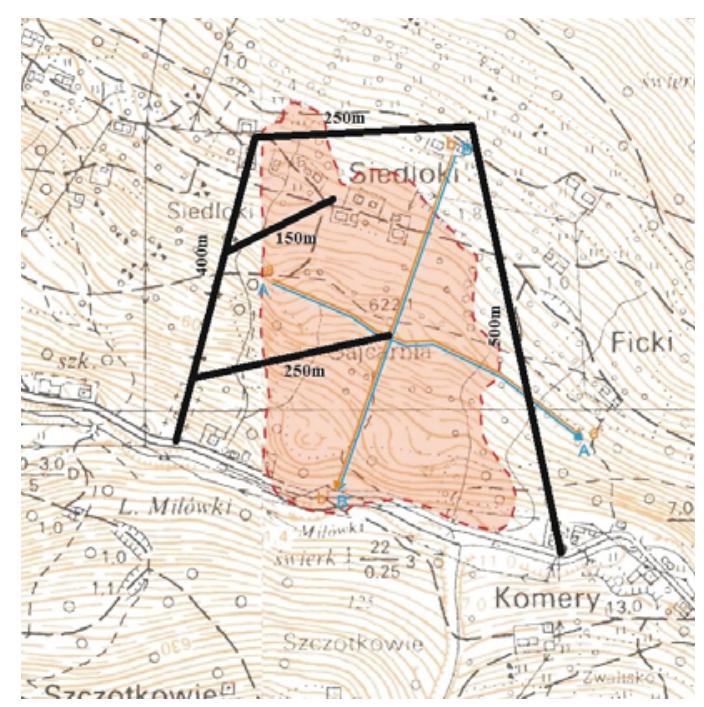

FIGURE 8. Proposed scheme for linear landslide drainage in Milówka Siedloki (Dziedzic and Golan 2016)

have good transpiration properties (e.g. alfalfa, rye, oats, larch, beech). It would be possible to resign from the latter, provided that regular grass trimming will be planned and conducted, which was neglected after 1989. There are many indications that the abandonment of agricultural fields, that absorb huge amounts of water from the soil, is one of the important factors affecting landslide activity (especially in Milówka).

\section{Numerical analysis of the stability of the landslide in Milówka Prusów and Siedloki}

The article presents the stability analysis of the Milówka-Prusów slope, where in 2010 a landslide started. Correctness of stability analyses can be assessed by knowing the soil conditions and the existing deformations (Documentation 2016). After verifying the correctness of the assumptions, the conclusions from the analyses may be used for future calculations, which may be part of the monitoring of landslide danger. Some simplifications are always used when creating the model. They arise from the limitations concerning the available methods and programs, which are tools for solving a given issue. Lack of proper ground tests is also often a limitation, especially in terms of the parameters of the model adopted for the calculation.

The most popular material model for stability analysis of slopes is the elastic-perfectly plastic model with a Coulomb-Mohr failure criterion. The required values of parameters are the Young's modulus $(E)$ and the Poisson's ratio ( $v)$, which describe the behaviour of the soil in the elastic range and the effective angle of internal friction $\left(\varphi^{\prime}\right)$ and effective cohesion $\left(c^{\prime}\right)$. Usually, a plane model is analysed using the assumptions of a plane strain. Finite elements used are a four-node quadrangle. There were three variables in each node: 
two displacements (horizontal and vertical) and the value of pore pressures. The size of the model should be definitely larger than the expected range of the landslide. Also, the depth of the model should be large enough not to affect the shape of the slip surface. The most frequent problem is too shallow exploration of the substrate in relation to the depth of the built model. In such case, it is usually assumed that the lowest discovered layer lies at the bottom of the constructed model.

The numerical model used in the calculations is shown in Figure 9a. The model limits the shape of the slope, which was mapped on the basis of geodetic meas- urements (Documentation 2010a, b). Most often, the model's floor is horizontal, which facilitates the task of boundary conditions. However, it is also allowed take a bottom that is parallel to the slope, which reduces the number of finite elements and causes a more favorable shape of these elements, which results in shortening the calculation time and improving convergence. In the present case, the second method of the model geometry selecting was used. In numerical analyses, the finite element method was used, and the stability was analysed using the previously described $c-\varphi$ reduction procedure. The soil should be analysed as a two-component medium consist-

a

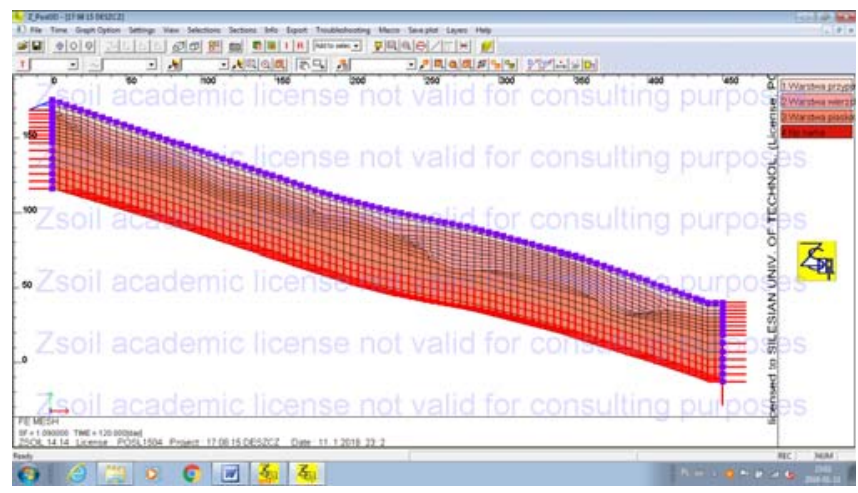

b

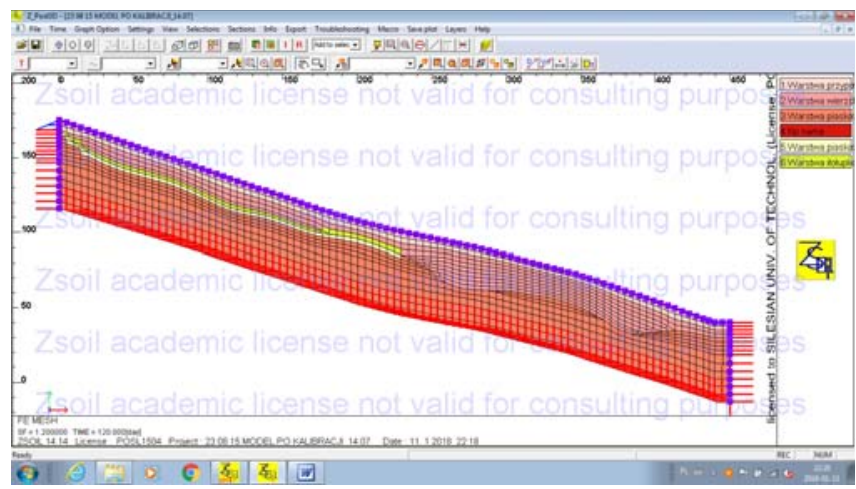

FIGURE 9. Numerical model in stability analysis: $a-$ on the basis of soil exploration; $b$ - on the basis of calibration including degradation of material (Dziedzic and Golan 2016) 
ing of a deformable solids and filtering water, because water in the ground plays a key part in the initiation and course of landslide processes. The filtration velocity is described by Darcy's law, and the relationship between the total stress, the effective stress and the pore pressure in the soil is determined by Terzaghi's law. The values of material parameters for calculations are summarized in the table (Dziedzic and Golan 2016). The boundary conditions in the deformation analysis of the solid were set in the form of non-displaceable supports on the bottom edge of the model and supports without the possibility of horizontal displacement at the side edges. The boundary conditions on the surface of the slope were automatically set as surface normal stress equal to zero. The boundary conditions of water filtration were set in the form of piezometric heights of water levels at the lateral edges, the height was provided based on the boreholes. On the bottom and top edges of the model, zero water flow rates were applied. Additionally, rain was included into analysis as an additional, forced stream of flow through the surface of the analysed slope (rainfall of $20 \mathrm{~cm} /$ day was assumed for two 10-day periods with 10-day break).

In the preliminary stage of the analysis, the stress state was determined, including the filtering phenomena in the substrate. At a later stage, the change in the stress state associated with rainwater infiltration was analysed. Both before and after the rain a stability analysis was carried out using the $c-\varphi$ reduction method. In addition, a variant with the forming of two layers simulating slip on the border of sandstones and weathering was analysed (Fig. 9b). In this variant, the following factors were considered: degradation of strength due to landslide initiation and increase of the filtration coefficient (the table). In order to be able to apply this variant of calculations, it is necessary to know the course of the forming slip surface and to be able to estimate the values of the degraded layers parameters. This information can be obtained from the analysis of monitoring results. The value of stability coefficient lower than 1.00

TABLE. Values of strength parameters for numerical analyses (Documentation 2011b, Dziedzic and Golan 2016)

\begin{tabular}{|l|c|c|c|c|c|c|}
\hline Material zone & $\begin{array}{c}\text { Bulk } \\
\text { density } \\
\left(\mathrm{kN} / \mathrm{m}^{3}\right)\end{array}$ & $\begin{array}{c}\text { Young's } \\
\text { modulus } \\
E(\mathrm{MPa})\end{array}$ & $\begin{array}{c}\text { Poisson's } \\
\text { ratio } \\
v(-)\end{array}$ & $\begin{array}{c}\text { Effective } \\
\text { internal } \\
\text { friction } \\
\text { angle } \\
\varphi^{\prime}\left({ }^{\circ}\right)\end{array}$ & $\begin{array}{c}\text { Effective } \\
\text { cohesion } \\
c^{\prime}(\mathrm{kPa})\end{array}$ & $\begin{array}{c}\text { Darcy's } \\
\text { factor } \\
k(\mathrm{~m} / \mathrm{s})\end{array}$ \\
\hline $\begin{array}{l}\text { Surface layer (sandy silty } \\
\text { clay with sandstone crumbs) }\end{array}$ & 21.0 & 17.5 & 0.32 & 26 & 6 & $5 \cdot 10^{-8}$ \\
\hline Top layer (shale) & 23.1 & 400 & 0.33 & 20 & 10 & $5 \cdot 10^{-7}$ \\
\hline Layer of sandstones & 25.0 & 3200 & 0.30 & 25 & 250 & $5 \cdot 10^{-9}$ \\
\hline $\begin{array}{l}\text { Layer of degraded } \\
\text { sandstones (only variant II) }\end{array}$ & 23.1 & 400 & 0.33 & 15 & 7.5 & $5 \cdot 10^{-7}$ \\
\hline $\begin{array}{l}\text { Layer of degenerate shales } \\
\text { (only variant II) }\end{array}$ & 25.0 & 3200 & 0.30 & 25 & 7,5 & $5 \cdot 10^{-7}$ \\
\hline
\end{tabular}


was obtained by proportional increase of strength of all layers of the model with the same reduction of the obtained result.

The stability coefficient value is 1.21 , with the parameter values based on subsoil exploration and water filtration under typical atmospheric conditions (Fig. 10a). The value is so high that it can be assumed that the slope is safe. In the case of heavy rains, this value decreases to 1.07 (Fig. 10b), which should be treated as a serious risk of initiating landslide

a

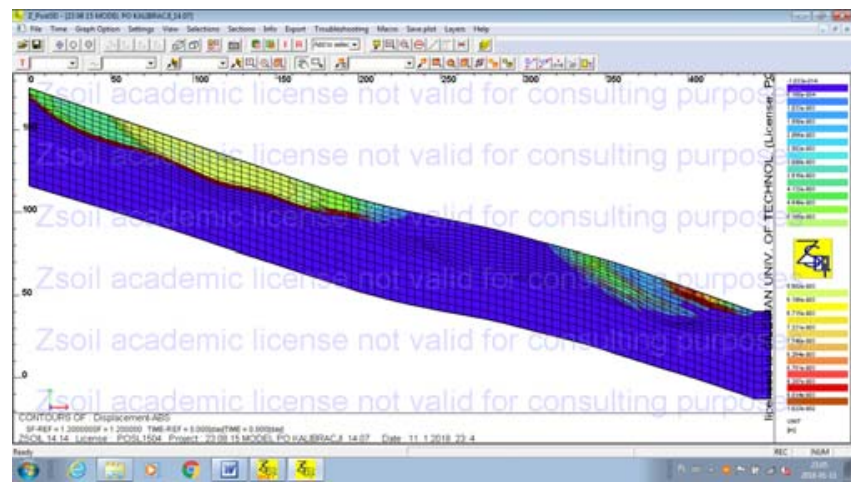

b

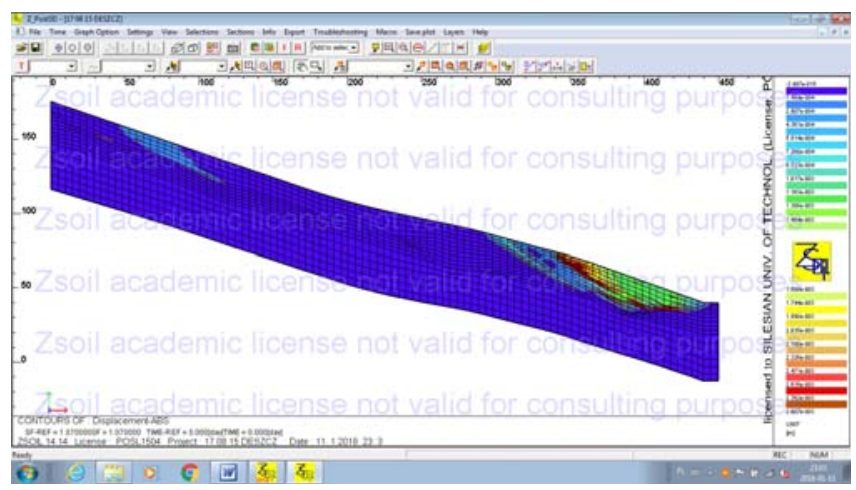

c

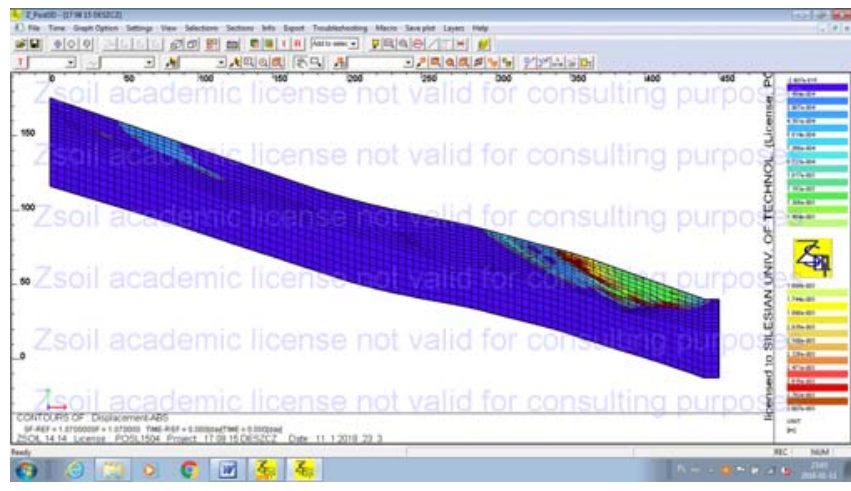

FIGURE 10. Slip surface shape: a - under typical atmospheric conditions; $b$ - under heavy rains; c - model after calibration (Dziedzic and Golan 2016) 
processes. Thus, the influence of rainwater should be treated as the main risk factor for the emergence of mass movements.

The origin, range and form of soil mass movements can be accurately presented in the case of when detailed information about potential slip surfaces and the values of the parameters of the degraded layers forming the slip layer are provided. The value of the stability coefficient for variant II is 0.89 , and the form of loss stability quite well corresponds to the real slides (Fig. 10c). The shape of all slip surfaces is flattened and approximately parallel to the slope surface. This is the result of the formation and stratification in the substrate, as well as the formation of preferential filtration directions and the simultaneous effect of the hydrostatic pressure. Thus, the proposed method of analysis can be very effective provided that proper values of the model parameters and the stratification are used.

\section{CONCLUSIONS}

With regard to the presented analyses, it can be concluded that water is the main factor initiating the landslide processes. This is due to both observations and numerical analyses. Thus, the key task for the land manager is to properly drain the water when it suddenly occurs, which happens mainly with heavy rains. Proper removal of water is the efficient drainage or cultivation of appropriate plant species that guarantee bioretention. In addition, the plant root system may provide additional reinforcement of the slope, which increases the safety of its use.
Another aspect of the protection of the slopes against the landslide is proper monitoring system, which should include both soil exploration and regular displacement measurements. The conclusions from the deconcentricity of trees annual growth can be additionally used. The monitoring is supplemented by numerical analyses, including the most important slope stability analyses, on the basis of which the current safety margin can be assessed. The method of stability analysis based on the FEM proposed in the paper makes it possible to obtain a reliable mechanism of destruction. Having such tools at their disposal, the responsible entities can definitely make easier the important decisions regarding the safety of people using the endangered areas and structures located there.

\section{REFERENCES}

BEGEMANN W., SCHIECHTL H.M. 1999: Inżynieria ekologiczna w budownictwie wodnym i ziemnym [Ecological engineering in hydrous and ground construction]. Arkady, Warszawa [in Polish].

BUTLER D.R. 1987: Teaching general principles and applications of dendrogeomorphology. J. Geol. Ed. 35 (2): 64-70.

CEMPURA Ł., KOS J., SOKALSKI J. 2009: Mapa osuwisk i terenów zagrożonych ruchami masowymi ziemi dla gminy Milówka [Map of landslides and areas threatened by mass land movements for the Milówka commune]. Przedsiębiorstwo Geologiczne, Kraków [in Polish].

Documentation 2010a: Operat pomiarowy. Monitoring geodezyjny osuwisko „Prusów” w Milówce. Obserwacja przemieszczeń osuwiska w dniach: 13.09.2010-11.10.2010 [Measuring elaboration. Geodetic monitoring of the landslide „Prusów” in Milówka. Observation of landslide dislocations on: 13.09.2010-11.10.20101]. Usługi Geodezyjne „Geo-Profil” s.c., Żywiec [in Polish]. 
Documentation 2010b: Operat pomiarowy. Monitoring geodezyjny osuwisko „Prusów” w Milówce". Obserwacja przemieszczeń osuwiska w dniach: 11.10.2010-27.12.2010 [Measuring elaboration. Geodetic monitoring of the landslide „Prusów” in Milówka. Observation of landslide dislocations on: 11.10.2010-27.12.2010]. Usługi Geodezyjne „Geo-Profil” s.c., Żywiec [in Polish].

Documentation 2011a: Badania geofizyczne osuwisk karpackich w ramach tematu: „System Osłony Przeciwosuwiskowej SOPO - etap II - 2011 rok" [Geophysical tests of the Carpathian landslides under the theme: „SOPO antilandslides system - stage II - 2011"]. Przedsiębiorstwo Badań Geofizycznych Sp. z o.o., Warszawa [in Polish].

Documentation 2011b: Wykonanie badań laboratoryjnych próbek pobranych $\mathrm{z}$ wierceń pełnordzeniowych, wykonanych na 15 monitorowanych obiektach osuwiskowych wraz z interpretacją i dokumentacją końcową zawierającą opracowanie warunków geotechnicznych dla potrzeb monitoringu wgłębnego osuwisk. Osuwisko „Milówka” [Realisation of laboratory tests of samples taken from full-core drilling, carried out on 15 monitored landslides, including interpretation and final documentation with the elaboration of geotechnical conditions for the needs of deep landslide monitoring. Landslide „Milowka”]. Politechnika Krakowska, Kraków [in Polish].

Documentation 2016: Karta dokumentacyjna osuwiska. Numer ewidencyjny 24-17-092 [Landslide documentation card. The registration numer 24-17-092]. Państwowy Instytut Geologiczny - Państwowy Instytut Badawczy, Oddział Karpacki, Kraków [in Polish].

DZIEDZIC G., GOLAN A. 2016: Analiza zjawisk osuwiskowych we fliszu karpackim na przykładzie osuwiska w Milówce Prusów [Analysis of landslide phenomena in the Carpathian flysch on the example of a landslide in Milówka Prusów]. Master's thesis, The Silesian University of Technology [in Polish].

EN-1997-1:2004. Eurokod-7. Geotechnical Design. Part 1: General rules.

GARDAS Ł. 2011: Osuwisko w Milówce-Prusowie czeka na inwestycje. Dziennik Zachodni z 14.04.2011.
Instruction 2009: Ocena stateczności skarp i zboczy. Zasada wyboru zabezpieczeń [Stability assessment of slopes and escarpments. The principle of the protection selection]. Instrukcja ITB, Warszawa [in Polish].

Instruction Id-3 2009: Warunki techniczne utrzymania podtorza kolejowego [Technical conditions for maintaining the railway subgrade]. PKP PLK S.A., Warszawa [in Polish].

MADEJ J. 1981: Metody sprawdzania stateczności zboczy [Methods of verification of the slope stability]. WKŁ, Warszawa [in Polish].

KŁOSIŃSKI B., LEŚNIOWSKI Ł. 2009: O wymaganiach dotyczących stateczności zboczy i skarp [The requirements for the stability of slopes and escarpments]. Zesz. Nauk. Techn. SITK, Kraków. Mat. konf. Problematyka osuwisk w budownictwie komunikacyjnym 88 (144) [in Polish].

SHRODER J.F. 1980: Dendrogeomorphology: review and new techniques of tree-ring dating. Prog. Phys. Geogr. 4 (2): 161-188.

WIŁUN Z. 2013: Zarys geotechniki [Geotechnical outline]. 10 edn. WKt, Warszawa [in Polish].

WISTUBA M., MALIK I. 2011: Indeks dekoncentryczności przyrostów rocznych drzew — narzędzie do identyfikacji współczesnych ruchów osuwiskowych [Index of the annual tree-ring eccentricity - a tool for identifying the modern landslide movements]. Czas. Geogr. 82 (4): 401-421 [in Polish].

WISTUBA M., MALIK I., GÄRTNER H., KOJS P., KRĄPIEC M. 2012: Zastosowanie dekoncentryczności przyrostów rocznych świerka pospolitego (Picea abies Karst.) w analizie dynamiki osuwiska - przykład z masywu Hrubégo Jeseníka (Sudety Wschodnie) [Application of tree-ring eccentricity above Norway spruce (Picea abies Karst.) in the analysis of landslide dynamics - example from the Hrubé Jeseník massif (Eastern Sudetes)]. Stud. Mat. CEPL Rogów 14 (30): 185-194 [in Polish].

WISTUBA M., MALIK I., PIĄTEK M., KOJS P., KALINOWSKI M., POLOWY M. 2013: The use of wood anatomy features for landsliderisk assessment and early warning - an example from Western Carpathians, Poland. Geoph. Res. Abstr. 15 (EGU2013-9899). EGU General Assembly. 
WISTUBA M., MALIK I., POLOWY M., MICHAŁOWICZ P. 2014: Zastosowanie dekoncentryczności przyrostów rocznych w badaniach stoku o wysokim zagrożeniu osuwiskowym (Milówka, Beskid Żywiecki) [Application of tree-ring eccentricity in studies of a slope with high landslide hazard (Milówka village, Beskid Żywiecki Mts)]. Stud. Mat. CEPL Rogów 16 (40): 130-138 [in Polish].

Streszczenie: Analiza przyczyn i skutków osuwisk we fliszu karpackim na terenie gminy Milówka oraz ocena metod ich zapobiegania. Praca stanowi obszerne stadium dotyczące przyczyn i skutków osuwisk występujących $\mathrm{z}$ różnymi okresami intensywności na terenie gminy $\mathrm{Mi}$ lówka od 1947 roku aż do dziś. Inwentaryzację stanu istniejącego wykonano na podstawie wizji lokalnej osuwisk w Nieledwi, Przysiółku Siedloki i na górze Prusów oraz na podstawie materiałów otrzymanych z Państwowego Instytutu Geologicznego w Krakowie i Urzędu Gminy Milówka. Pełna analiza objęła wytypowanie prawdopodobnych przyczyn tworzących się osuwisk oraz dyskusję nad możliwymi metodami zaradczymi, w tym profilaktycznymi. Pod uwagę wzięto również właściwości wegetacyjne i transpiracyjne roślin oraz upraw rolnych. Zwrócono również uwagę na dekoncentryczność przyrostów rocznych drzew. Dodatkowo przeprowadzono analizę numeryczną stateczności osuwiska $\mathrm{w}$ stanie aktualnym w programie Z_Soil. Za podstawę do budowy modelu przyjęto przekroje wyznaczone metodami sejsmicznymi i elektrooporowymi, które dość wiernie oddają skomplikowaną budowę geologiczną fliszu karpackiego. Parametry gruntowe uzyskano z badań laboratoryjnych oraz geofizycznych. Rozważono możliwości uwzględnienia w obliczeniach numerycznych opadów atmosferycznych w postaci infiltracji wody w głąb zbocza przez system szczelin i spękań.
Ostatecznie stwierdzono, że biorąc pod uwagę liczbę założeń koniecznych do przyjęcia w ramach analizy numerycznej, określenie dokładnej wartości współczynnika stateczności nie jest możliwe. Można natomiast wytypować $\mathrm{z}$ dużym prawdopodobieństwem zbocza zagrożone osunięciem. W tym celu autorzy sugerują skorelowanie danych odnośnie aktywności osuwiskowej, pochodzących z Narodowego Archiwum Geologicznego, z danymi z meteorologicznymi i danymi z urzędów statystycznych, które dotyczą zasięgu i intensywności gospodarki rolnej na terenach osuwiskowych (lub wycinki drzew, jeżeli takie dane istnieją). Ponadto stwierdzono, że zmienność masywów fliszowych uniemożliwia wypracowanie rozwiązań uniwersalnych. Często dobrym zabezpieczeniem jest stosowanie tradycyjnych metod stabilizacji w połączeniu z metodami naturalnymi takimi jak planowanie wykoszeń trawy na obszarze osuwiska i/lub obsadzenie powierzchni osuwiska drzewami lub roślinami wysokoenergetycznymi. Każdorazowo konieczne jest indywidualne podejście do zagadnienia.

Stowa kluczowe: osuwiska, analiza stateczności zboczy i skarp, gmina Milówka

\section{MS received 29.01.2018 \\ MS accepted 04.06.2018}

\author{
Authors' address: \\ Małgorzata Jastrzębska, Marian Łupieżowiec \\ Katedra Geotechniki i Dróg \\ Wydział Budownictwa \\ Politechnika Śląska \\ ul. Akademicka 5, 44-100 Gliwice \\ Poland \\ e-mail: malgorzata.jastrzebska@polsl.pl \\ marian.lupiezowiec@polsl.pl
}

